\title{
ELEMZÉSI KERET A HAZAI KÖZPONTOSÍTOTT KÖZBESZERZÉSEKHEZ HATÉKONYSÁGNÖVELÉS ÉS MODERNIZÁCIÓ
}

A közbeszerzések központosításáról szóló döntés komoly gazdasági hatású, éppen ezért fontos, hogy összetett elemzés előzze meg. A szerzők tanulmányának célja, hogy a vállalati gyakorlatban logikailag hasonló szervezeti centralizációval kapcsolatos kutatások eredményeiből kiindulva, és a közbeszerzési nemzetközi szakirodalom, valamint szakmai interjúk eredményeire építve elemzési keretet alakítson ki. A szempontrendszer értelmezéséhez azonosítják a hazai központi közbeszerző szervezeteket, feltárják jellegzetességeiket, összehasonlítják tevékenységeiket. Az elemzési keretrendszer így mindegyik létező és esetlegesen kialakuló későbbi központi beszerző szervezet működési logikájának megértésére hasznos lehet, figyelemmel a változó jogi környezetre és a központosítás jellegére. ${ }^{1}$

\section{Kulcsszavak: közbeszerzés, beszerzés, központosítás}

A hazai és a nemzetközi közbeszerzési szakirodalom nemigen szentelt eddig figyelmet azon struktúrák elemzésének, amelyek a központosított közbeszerzési rendszerek alapjait alkotják. Mindenképpen érdekes kérdésről van szó, hiszen a központosított közbeszerzésben jellemzően nagy beszerzési érték önmagában is fontossá teszi a vizsgálatot. Cikkünk kiinduló pontja, hogy a nemzetközi szakirodalom igen nagy terjedelemben foglalkozik mind a beszerzési, mind a közbeszerzési gyakorlat strukturális vizsgálatával. Ezek az eredmények alapot jelenthetnek a hazai keretek értékeléséhez és továbbgondolásához is. Cikkünkben a szakirodalom eredményeinek felvillantása után a jelenleg azonosítható hazai három központi beszerző szervezettel (Közbeszerzési és Ellátási Főigazgatóság, Állami Egészségügyi Ellátó Központ, Nemzeti Kommunikációs Hivatal) kapcsolatos tapasztalatokat szintetizáljuk. Célunk egy olyan logikai keretet kialakítása, amely sokrétüen tükrözi az érintett szervezetek felépítésének jellegzetességeit, tagjaik céljait és elvárásait. Ez a logikai keret későbbi kutatások, nemzetközi összehasonlítások alapját is képezheti, illetve segítheti az érintett közbeszerzési szervezetek modernizációját és tevékenységük esetleges átgondolását.

\section{Szakirodalmi alapok}

A beszerzés szervezeti kerete, a közvetlen szervezeti határokon átnyúló vagy különálló szervezetek által közösen végzett beszerzési folyamatok számos beszerzési és közbeszerzési kutatás középpontjában állnak. Mivel mind a vállalati, mind a közszféra beszerzési tevékenységének fó célja hasonló (a szervezet inputokkal való ellátása), így érdekes lehet a publikált eredmények együttes végiggondolása. Cikkünk ezért röviden áttekinti azokat a föbb szakmai kérdéseket, eredményeket, amelyek egy a hazai közbeszerzési gyakorlat strukturális kereteinek elemzésére alkalmas szempontrendszer kialakítását meghatározzák.

\section{A beszerzési központ és azok szervezeti kereteinek kialakulása}

A szervezetek beszerzési döntéseivel foglalkozó korai szakirodalmak közül talán a legismertebb Robinson et al. (1967) könyve, amelyben a beszerzési döntésben érintettek körét beszerzési központnak nevezi. A nemzetközi szakirodalom számos vonatkozásban vizsgálta ezt a koncepciót (Johnston - Bonoma, 1981). Cikkünk témája szempontjából azok az eredmények lényegesek, amelyek azt figyelik, hogy a beszerzési tevékenység fontosabb lépései, hogyan kerülnek szervezetileg is egy központba, azaz hogyan jön létre és kap egyre több feladatot a beszerzési szervezet. Ennek a folyamatnak a középpontjában a beszerzési feladatok jelentőségének felértékelődése áll, a kutatók és a vállalati gyakorlat egyaránt felismerik azt, hogy az inputok megszerzése hatékonyabb és kontrollálhatóbb, ha nem az igénylő végzi, hanem egy olyan szervezet tudja biztosítani, amely független az igénylötől, s áttekinthető folyamatok szerint dolgozik (Schiele, 2007). A vállalati gyakorlatban ez azt jelentette, hogy az ajánlatkérési, szállítómenedzsment és szerződéskötési feladat az igénylő területektől, így főként a termeléstől, de a marketingtől, pénzügytől stb. egyre inkább a beszerzési szervezethez került. A hazai beszerzési szaknyelvben központosításnak nevezett folyamat lényege, hogy a beszerzési szervezet a vállalati tevékenységek elvégzéséhez szükséges kiadások - kivéve a humán és az adó jellegü kiadásokat, amelyeknél a beszerzés eszköztára nem alkalmazható hatékonyan - kontrolljáért válik felelőssé (Vörösmarty - Tátrai, 2017). A beszerzési feladatok központosításának előnye a kiadások jobb tervezhetősége, az ellenőrizhetőbb beszerzések, valamint a szakszerübb, hatékonyabb és eredményesebb eszközrendszer (Vörösmarty - Tátrai, 2017; Baily - Farmer, 1994). Ugyanakkor alapelvárásként jelenik meg az ellátásbiztonság megfelelő szintjének megtartása. A különböző kutatások egyértelműen jelzik, hogy a beszerzés központosításának gyakorlata és a beszerzés szakmaiságának fejlődése hoz-

Köszönetnyilvánítás: A tanulmány az NKFI támogatásával készült. (K 124644) 
zájárul a vállalati eredményességhez (Úbeda et al., 2015; Rozemeijer et al., 2003).

Lényegében hasonló szempontok jelennek meg a közbeszerzési gyakorlatban is, sajátos módosulással. Rendon és Snider (2010) szerint a közbeszerzés hármas keretrendszerben dolgozik: hatással vannak rá a menedzsment, jogi és politikai keretek. Ez egyben azt is jelenti, hogy egy szervezet beszerzésében figyelemmel kell lenni az adott szervezet céljaira, pénzügyi kereteire, be kell tartani a szabályozási kereteket és figyelni kell a jogalkotó céljaira (pl. KKV-k támogatása). A hazai vizsgálatok azt mutatják, hogy a jogszabályi keretek a közbeszerzési szervezetekre jelentős hatást gyakorolnak (Vörösmarty - Tátrai, 2017), ugyanakkor egyre inkább megjelennek példák a hatékonyság keresésére is. Léteznek koncepciók arra nézve, hogy milyen elönyei vannak a központosításnak, de nem történt meg annak összefoglalása, és olyan elméleti szakirodalom sem található, ami segít meghatározni azokat a jellemzőket, melyek a központosításról szóló döntés során felvetődnek. A beszerzés dedikált jogi támogatása, a szervezeti keretek elkülönített módon történő jogi támogatása jellegzetes megoldás azoknál a gazdasági szereplőknél, ahol a piaci viszonyok eleve nagyon szabályozottak, és a beszerzési tudást az ágazati jogszabályok ismerete kell, hogy közvetlenül kiegészítse. Azaz itt a beszerzési központ fogalma egy sokkal lazább keretet jelent szervezeti vonatkozásban, mint azt az üzleti szféra vállalatainál láthattuk, ugyanakkor a közbeszerzési folyamatok lebonyolításához szükséges szakértelem igénye sokkal határozottabban jelentkező elvárás.

\section{A beszerzési szervezetek közötti koordináció}

A szakirodalomban egyre inkább felvetődik a kérdés, hogy a beszerzési központ/beszerzési szervezet hogyan végezhetné a feladatát hatékonyabban (például Dimitri et al., 2006). A hatékonyság keresésének számos megoldása van. Cikkünk szempontjából azokat emelnénk ki, amelyekkel a beszerzési központok szervezeti határait érintik. Ez jelentheti egyrészt azt, hogy egy nagyobb szervezet központja a kisebb egységeitől (pl. leányvállalataitól) hogyan vonja el a beszerzési feladatokat, vagy enged önállóságot (centralizálás, decentralizálás). Egy másik lehetséges formája, hogy a rendszerint kisebb és tulajdonosilag független vállalatok beszerzési szervezetei hogyan lépnek szövetségre egymással (kooperatív beszerzés), s végeznek közösen beszerzési feladatokat. Mindkét forma jellemzöje, hogy a megvalósításnak számos módja létezik, amely az információátadástól, a közös tervezésen át a beszerzési feladatok egyetlen beszerzési szervezetbe való összevonásig terjedően számos köztes megoldást lehetővé tesz, mely a tartalmát tekintve sokszínủ lehet (Kamann, 2004).

A vállalatokkal foglalkozó kutatások egyértelmủen a hatékonysággal kapcsolatos szempontokat jelenítik meg mind a centralizáció, mind a kooperatív beszerzés okaként. A centralizáció számos szinergiahatást eredményezhet (Rosemeijer, 2000; Faes et al., 2000; Smart - Dudas, 2007) amelyek akár alacsonyabb árakban, jobb beszállítói teljesítményben jelentkeznek. Ezek jelentős részben a jobb piaci alkuerőnek tudhatók be. Ugyanakkor a szinergia- hatás jelentkezhet abban is, hogy csökken a párhuzamos munkavégzés és könnyebb a megfelelő szaktudás biztosítása (Trautmann et al., 2009; Karjalainen, 2011).

Hasonló előnyöket tulajdonít a szakirodalom annak is, amikor több független szervezet fog össze. Bár ennek az együttmüködésnek több formája is létezik, amelyeknek az előnyei és hátrányai különbözőek (Schotanus - Telgen, 2007), általában elmondható, hogy azáltal, hogy több szervezet beszerzési igényét vonják össze, megnő az alkuerö, ami lehetővé teszi kedvezőbb szállítói kondíciók elérését. Tella és Virolainen (2005) kutatása szerint elsősorban a kedvezőbb árat és a piaci információhoz való jobb hozzáférést emeli ki az előnyök közül.

A beszerzési modellek esetében legyen szó akár a centralizálás kérdéséről, vagy a független szervezetek önkéntes kooperációjáról a működési költségek alakulása, a költségek megosztása mindenképpen kulcskérdés. S bár mint láthattuk az elönyök között kiemelt helyen szerepelnek az árban elért megtakarítások, ezek önmagukban nem értékelhetőek, csak a teljes folyamatköltségek figyelembevételével (Karjalainen, 2011; Rendon - Snider, 2010).

Eltérés van viszont a két forma között a kontroll szempontjából. A nagyvállalat beszerzéseinek centralizálása során előnyt jelenthet a növekvő kontroll, hiszen a vállalati központ rálátása sokkal közvetlenebb, könnyebb a vállalati stratégiával való összhang megteremtése (Rosemeijer, 2000). A független szervezetek közös beszerzése viszont felveti a kontroll gyengülésének lehetöségét (Munson, 2007). Az igénylővel való koordináció igénye azonban mindkét formánál növekedhet, ami többletköltségeket jelenthet.

Hasonló eredmények olvashatók a közbeszerzéssel kapcsolatos kutatásokban is.

Eriksson et al. (2011) szerint a teljesítésre van kifejezetten pozitív hatása a közös közbeszerzésnek, míg Blair és Janousek (2013) elsősorban a helyi vállalkozások és a kollaboratív közbeszerzések kapcsolatáról értekezik. A kutatás során tehát számtalan olyan egyéb aspektusra hívják fel a figyelmet az elemzők, melyek hozzájárulnak a közös beszerzés sikeréhez. Erre az egyik legérdekesebb példa Erridge (2000), aki könyvében az együttmüködés professzionális oktatása nyomán elérhető alacsonyabb költségekről számol be. Tehát az együttműködés ilyen módját is kifejezetten a közös beszerzés gyakorlati példái közé sorolja Kim et al. (2012) az együttműködő és az opportunista szervezetközi viselkedési formát azonosítja. A kutatás eleve arra épít, hogy mennyi minden múlik a szereplők saját döntésén, bizalmán, hozzáállásán és ennek megfelelöen együttmüködési készségén, kockázatvállalási képességén, tudásmegosztás szintjén. Gyakori az együttmüködést függőségi szempontból is elemezni. Felmerül továbbá Ranjay - Sytch M. (2007) munkájában az ún. „joint dependence” értelmezése a beszerzési kapcsolatokban. Több kutatás foglalkozik ugyanakkor az együttmüködés okaival, motivációjával (Wang et al., 2005, 2006; Essig, 2000; O’Brien, 1995, Nyikos - Soós, 2018).

O’Brien (1995) kifejezetten a költségcsökkentés és a szolgáltatásfejlesztés célját határozza meg, mely közös 
közbeszerzési megállapodáshoz vezet a közszolgáltatói szektorban. Wang et al. (2005) szerint egészen addig tart a beszerzők motivációja, amíg a koordináció költsége elég alacsony. Wang et al. (2006) kutatását folytatva részletesen elemzi, hogy milyen feltételek vezetnek a közös beszerzési stratégia választásához. Teabok et al. (2006) pedig kifejezetten a közös beszerzés - termelés - ellátás hármasát kutatja, ahol a közös beszerzés egyértelmüen gazdaságos megoldást is feltételez.

Az egyes megoldások fejlettségi szintjét azonban elsősorban a bizalom, elhivatottság, a kommunikáció intenzitása, a közös munka iránti hajlandóság mint kritikus sikerkritériumok határozzák meg, amelyek elösegítik a kooperációt, integrációt. Ezt vizsgálja Grudinschi et al. (2014) is, kiemelve többek között azt, hogy a kommunikáció, a bizalom és a kormányzat beleszólása milyen mértékben van hatással az együttmüködésre, annak gördülékeny megvalósulására. Véleménye szerint, minél nagyobb az együttmüködés kockázata, annál nagyobb szerepe van a bizalomnak, kommunikációnak és az együttmüködés minőségének.
A fenti szakirodalmi tapasztalatokat egészíti ki az egyik leghasználhatóbb elemzés az Európai Unió közös közbeszerzési megoldásai hatékonysága vonatkozásában, a PWC-Ecorys jelentése (PWC-Ecorys Riport, 2011). 2006-2010 között közös megoldás az eljárások értékének $12 \%$-ban volt fellelhető, mely vélhetően az összes beszerzés során központi beszerző szervezet, vagy több ajánlatkérő által indított beszerzésekre vonatkozik. Előnyként tekinthető, hogy több ajánlat érkezett be közös beszerzés során. Fontos megállapítás, hogy a közös beszerzés elsősorban nem alacsonyabb árakhoz vezet, igaz, az aggregáció maga olyan adminisztrációcsökkenést eredményezett, mely áttételesen minden szereplő számára költségcsökkenéssel jár. A közös beszerzés során a szakmaiság szerepe nagyobb volt, bár többet is költöttek a tudás megszerzésére, a szakértők megtartására. A közös beszerzés megvalósítása az elemzés értelmében drágább és több képzett szakembert igényel.

A szakirodalmi eredményeket összefoglalva kiemelhető, hogy a struktúra kialakításának eltérő megoldásait vizsgálja a szakirodalom. A fö szempontokat, amelyek

1. táblázat A szervezeti megoldások elemzési szempontjai a szakirodalom alapján

\begin{tabular}{|c|c|c|c|}
\hline & Vizsgálati szempor & & Hivatkozás \\
\hline 1 & Szervezet: & A központi beszerző szervezet felépítése & $\begin{array}{l}\text { Vörösmarty - Tátrai (2017); } \\
\text { Trautmann et al. (2009); Karjalainen (2011); } \\
\text { Baldi - Vannoni (2017); Johnson et al. (2003) }\end{array}$ \\
\hline 2 & Humán erőforrás: & A humán erőforrás minősége & $\begin{array}{l}\text { PWC-Ecorys Riport (2011); Trautmann et al. } \\
\text { (2009); Karjalainen (2011); Rosemeijer (2000) }\end{array}$ \\
\hline 3 & Szabályozás: & $\begin{array}{l}\text { A szabályozás mértéke, tartalma, színvonala, } \\
\text { módosítás gyakorisága }\end{array}$ & $\begin{array}{l}\text { Rendon - Snider (2010); Vörösmarty - Tátrai } \\
\text { (2017); Bals et al. (2018) }\end{array}$ \\
\hline 4 & Kommunikáció: & $\begin{array}{l}\text { A központi beszerző szervezet kommunikációja } \\
\text { az igénybevevőkkel, ajánlattevőkkel, jogalkotóval, } \\
\text { hatóságokkal }\end{array}$ & $\begin{array}{l}\text { Tella - Virolainen (2005); Grudinschi et al. } \\
\text { (2014); Vagstad et al. (2000) }\end{array}$ \\
\hline 5 & Együttmüködés: & $\begin{array}{l}\text { A központi beszerző szervezet együttműködései } \\
\text { az igénybevevőkkel }\end{array}$ & $\begin{array}{l}\text { Rosemeijer (2000); Faes et al. (2000); Scho- } \\
\text { tanus -Telgen (2007); Erridge (2000); Kim } \\
\text { et al. (2012); Wang et al. (2005, 2006); Essig } \\
\text { (2000); O’Brien (1995); Smart - Dudas (2007) }\end{array}$ \\
\hline 6 & Folyamatok: & A központi beszerző szervezet belső folyamatai & $\begin{array}{l}\text { Kamann et al. (2004); Rosemeijer (2000); } \\
\text { Schiele (2007) }\end{array}$ \\
\hline 7 & Piaci kapcsolatok: & $\begin{array}{l}\text { A központi beszerző szervezet és a potenciális } \\
\text { ajánlattevők között kapcsolat }\end{array}$ & Rosemeijer (2000); Faes et al. (2000) \\
\hline 8 & Szabadságfok: & Központi beszerző szervezet döntési szabadsága. & Kamann et al. (2004); Ranjay - Sytch (2007) \\
\hline 9 & Viszonyrendszer: & $\begin{array}{l}\text { Központi beszerző szervezet és az ajánlatkérők } \\
\text { közötti viszonyrendszer }\end{array}$ & Kim et al. (2012) \\
\hline 10 & Finanszírozás: & A finanszírozása modell & Rendon - Snider (2010) \\
\hline 11 & Ellenőrzés: & A központi beszerző szervezet ellenőrzése & Vörösmarty - Tátrai (2017); Rosemeijer (2000) \\
\hline 12 & Tevékenységi kör: & $\begin{array}{l}\text { A központi beszerző szervezet által végzett } \\
\text { szolgáltatás tartalma }\end{array}$ & $\begin{array}{l}\text { Úbeda et al. (2015); Rozemeijer et al. (2003); } \\
\text { Vörösmarty - Tátrai (2017) }\end{array}$ \\
\hline 13 & Termékportfólió: & $\begin{array}{l}\text { A központi beszerző szervezet által beszerzendő } \\
\text { termékek, szolgáltatások köre }\end{array}$ & $\begin{array}{l}\text { Rosemeijer (2000); } \\
\text { Munson (2007) }\end{array}$ \\
\hline 14 & Kartellveszély: & $\begin{array}{l}\text { A központi beszerző szervezet közbeszerzési } \\
\text { eljárásai során a kartell kialakulásának kockázata }\end{array}$ & Havighurst (1995); Normann et al. (2015) \\
\hline 15 & Fenntarthatóság: & $\begin{array}{l}\text { Zöld, szociális, innovatív szempontok } \\
\text { alkalmazása a beszerzés során }\end{array}$ & PWC-Ecorys Riport (2011) \\
\hline
\end{tabular}


szerint az egyes struktúrákat megkülönböztethetjük a következőképpen összegezhetjük:

- a központ tevékenységének tartalma,

- a költségek megosztása,

- a kontroll jellege,

- a csatlakozás jellege.

Az egyes különböző modellek értékelésének lehetséges szempontjait a szakirodalom alapján az 1. táblázat foglalja össze.

\section{Módszertan}

Mint látható, a feltárt szakirodalom számos szempontot vizsgált, s a megállapításokat érdemes keretbe rendezni, hisz nincs olyan forrás, amely a problémát átfogóan közelítve rendszerezné a korábbi kutatások eredményeit. Cikkünkben a közös beszerzéssel, közbeszerzéssel kapcsolatos szakirodalmi eredmények összefoglalása mellett az eredmények kiegészítésére és ellenőrzésére a hazai központi beszerző szervezetek tevékenységének megismerésére is törekedtünk. Ilyen módon fontosnak tartjuk kiemelni a struktúra elemzését, illetve az egyes struktúrák értékelésére szolgáló szempontok rendszerbe foglalását. Ezen keretek vizsgálatához a releváns információk megszerzése érdekében interjúk készültek minden szervezet részéről olyan szakértőkkel, akiknek rálátásuk van a szervezet tevékenységére. Összesen tíz egyéni, mélyinterjú történt olyan szakemberekkel, akik beszállítói, illetve ajánlatkérői oldalon több, mint öt éves gyakorlattal rendelkeznek és mindennapi munkájuk során kapcsolatban kerülnek a központi beszerző szervezetekkel, valamint a téma jogszabályi hátterét ismerik. Interjúalanyainkat a Közbeszerzési Tanácsadók Országos Szövetségének tagjai közül választottuk. A strukturált interjúk készítését megelőzően a Budapesti Corvinus Egyetem közbeszerzéskutatásában közzétett kérdőív kitöltésére került sor (www. kozbeszkut.hu). Ehhez kapcsolódva mondták el véleményüket egyedileg az egyes szakértők a központi beszerző szervezetek vonatkozásában, amelyről saját bevallásuk szerint tapasztalattal rendelkeztek.

Cikkünkben elöször a jogszabályi háttérre való utalással és a szakértői információk segítségével felvázoljuk a hazai három megoldás fö jellegzetességeit. Célunk ezzel egyrészt, hogy összevethető módon leírjuk a hazai modellek alapján a lehetséges strukturális megoldások főbb jellemzöit. Másrészt, célunk az is, hogy keretbe gyüjtsük azokat a szempontokat, amelyek segítségével a közbeszerzések központosítására megalkotott különböző modellek/ szervezeti megoldások hatékonysága értékelhető.

Mindezek alapján lehetőség nyílt olyan keretrendszert kialakítani, szempontokat felsorolni, melyek a szakirodalom, a szabályzási környezet és a szakértői interjúk alapján meghatározzák e szervezetek tevékenységét és egyben determinálják müködésüket, befolyásolják hatékonyságukat, mely jelen kutatás célja volt.

\section{Központosított közbeszerzési modellek Magyarországon}

A központosított közbeszerzést hazánkban 1996-ban vezették be és tekinthető a közpénzköltés egyik meghatá- rozó hazai megoldásának. A központosítás hagyományosan kötelező érvényü, az igénybevevők számára meghatározott eljárásrenddel bíró, rigorózus szabályokkal átszőtt tevékenységhalmaz, melynek megítélése az elmúlt évtizedekben fokozatosan változott. Ehhez nagymértékben hozzájárul az elektronikus katalógusok megjelenése és a mindennapi kommunikáció elektronikus útra terelése, mely a központi beszerző tevékenységet modernizáló, hatékonyabb tevékenységellátást eredményezett. Jelenleg három központi beszerző szervezet azonosítható az alábbi szabályok értelmében, melyek sajátosságaikból, jellegzetességeikből adódóan más-más kihívásokkal néznek szembe.

A közbeszerzésekről szóló 2015. évi CXLIII. törvény értelmében központi beszerző szervezetnek, illetve központosított közbeszerzésnek az alábbiak minősülnek:

„25. központi beszerzö szerv: a központositott közbeszerzés során ajánlatkérésre feljogositott szervezet;

26. központositott közbeszerzés: központi beszerzö szerv által állandó jelleggel ellátott olyan tevékenység, amelynek célja

a) áruk vagy szolgáltatások megrendelése e törvény szerinti ajánlatkérők számára való továbbértékesités céljából, illetve

b) e törvény szerinti ajánlatkérők számára áruk beszerzésére, szolgáltatások vagy épitési beruházások megrendelésére irányuló szerződések vagy keretmegállapodások megkötése;"

A fenti definíció alapján az alábbi, jelenleg müködő központi beszerző szervezetek azonosíthatók

- Közbeszerzési és Ellátási Főigazgatóság,

- Állami Egészségügyi Ellátó Központ,

- Nemzeti Kommunikációs Hivatal.

A szakértői megkérdezés során konszenzus alakult ki abban a tekintetben, hogy nem minősül központi beszerző szervezetnek az Büntetésvégrehajtás Országos Parancsnoksága (továbbiakban BVOP) koordináló tevékenysége. Az egészségügyben müködő Nemzeti Egészségbiztosítási Alapkezelö (átalakuló OEP, továbbiakban NEAK) és az Országos Tisztifóorvosi Hivatal finanszírozási szempontból más-más modellben valósítják meg beszerzéseiket, központi beszerző szervezetnek a jogszabályi rendelkezések alapján nem tekinthetők, ezért fentiekben a hagyományos értelemben vett központi beszerző szervezetekkel foglalkozunk. Döntésünket a jogszabályi környezet vizsgálata során továbbá arra alapozzuk, hogy az érintett szervezetek saját kormányrendeleti szabályozása központi beszerző szervezetnek tekinti-e az adott szervezetet.

\section{Közbeszerzési és Ellátási Főigazgatóság}

A központosított közbeszerzési rendszer 1995 óta müködik hazánkban. Az első időszakban a központosított közbeszerzés elkerülése lényegesen könnyebb volt az intézményeknek. A katalógus hiánya, az igények összegyűjtésének kialakulatlansága, a tapasztalat hiánya nehézkesebb eljárásrendet, hosszadalmas eljárásokat eredményezett.

A központosított közbeszerzés során felhalmozódott tapasztalatok, az Európai Unióhoz történt csatlakozásunk a központosított közbeszerzés mindennapi gyakorlatát át- 
alakította. Fokozatosan Európa egyik legnagyobb központi közbeszerzési katalógusát alakították ki, melynek klasszifikációja a GS1 szabványrendszeren alapul, s a kommunikáció a központi beszerző szervezet és az ajánlatkérők, valamint részben az ajánlattevők között is elektronikus útra terelődött. Az időközben hatályba lépő, a központosított közbeszerzési rendszerről, valamint a központi beszerző szervezet feladat- és hatásköréröl 168/2004. (2004.V.25.) Korm. rendelet (továbbiakban KEF Rendelet) jelenleg is meghatározza a Közbeszerzési és Ellátási Főigazgatóság (korábbiakban Miniszterelnökség Közbeszerzési és Gazdasági Igazgatóság, a továbbiakban KEF) tevékenységét.

Eredeti célja a ráfordítások csökkentése, valamint a központi beszerzési rendszerben rejlő előnyök közigazgatási célú hasznosítása volt. A központosított közbeszerzés hatálya az évek során fokozatosan bővült. Jellegzetes központi beszerző szervezetről beszélünk, melynek beszerzési tárgyai is viszonylag jól parametrizálható beszerzési tárgyakat tartalmaznak. A hazai központosított rendszer egyértelmủen kötelező jellegü, csak a kormányrendeleti értelemben nem kötelezhető intézmények (például önkormányzatok) számára választható, ezt nevezzük önkéntes csatlakozásnak.

A kötelezettség az alanyi hatály alá tartozó intézmények vonatkozásában a KEF szolgáltatásának igénybevétele során az ún. kiemelt termékekre vonatkozik, mely az intézmény beszerzései között általánosan, illetve időszakosan visszatérő módon szereplő, azonos felhasználási célú és azonos müszaki, gazdasági vagy egyéb jellemzőkkel bíró termékeknek és szolgáltatásoknak a csoportja.

Szolgáltatását a KEF központosított közbeszerzési díj ellenében teszi, mely a központi beszerző szervezet által ellátott tevékenységért az intézmények által fizetendő ellenérték, maximum a becsült érték vagy szerződéses érték $2 \%$-a.

A KEF jellemzően ún. keretmegállapodásos eljárást bonyolít le, melynek eredményeként keretmegállapodást vagy keretszerződést köt. Ez utóbbi alapján szerződnek az eljárás második részében az egyes ajánlatkérők, használva ezzel a KEF „szolgáltatását”.

A szakértők külön felhívták a figyelmet arra, hogy a KEF központosított modell történelmi múltjából adódóan sokkal kialakultabb, biztosabb tevékenységet folytat. Ebben az esetben igen magas az önkéntes csatlakozók aránya például az önkormányzatok részéről, mely mutatja, hogy a közbeszerzés egyszerüsítése érdekében szívesebben választja sok ajánlatkérő a központosított közbeszerzést, annak kötöttségei, adatszolgáltatási kötelezettsége ellenére. Az önkéntes csatlakozás mértéke ugyanakkor itt boríthatja fel legjobban a tervezett mennyiségek fogyását és eredményeként merülhet ki a keretmegállapodás vagy keretszerződés. A szakértői vélemények külön kiemelték, hogy erre nagyon nehéz felkészíteni a szervezetet, tipikusan tapasztalati úton van lehetőség a változó igények megfelelő kiszolgálására. A stabil központi beszerző szervezetek egyik legnagyobb előnye pontosan az, hogy az igénybejelentések mellett a korábbi adatok, ismeret lehetővé teszik, hogy tapasztalati úton pontosabban legyen képesek az igények felmérésére. Ennek az informatikai támogatás szükséges, de nem elegendő feltétele.

\section{Állami Egészségügyi Ellátó Központ}

A következő központi beszerző szervezet a fekvőbeteg szakellátást nyújtó intézmények részére történő gyógyszer-, orvostechnikai eszköz és fertőtlenítőszer beszerzések országos központosított rendszeréről szóló 46/2012. (III. 28.) Korm. rendelet értelmében az Állami Egészségügyi Ellátó Központ (ÁEEK).

Hatályát tekintve az ÁEEK beszerzési tárgyköre igen széles. A kialakítás alatt álló katalógus különösen ezért fontos, hiszen megfelelö állami normatívarendszer és elektronikus katalógus hiányában rendkívül nehéz az intézmények számára szolgáltatást nyújtani. A beszerzési tárgyak az ÁEEK esetében a legegyszerübbtől a legbonyolultabbakig terjed, tekintettel az orvostechnikai eszközökre.

Ennek egyik legfontosabb eleme az igények felmérése. Az ÁEEK esetében az adatszolgáltatási kötelezettség, hasonlóan a KEF-hez rendkívül szigorú és részletes. A központi beszerző szervezet részére az intézmények kötelesek negyedévente adatszolgáltatást teljesíteni az intézmény által megvalósított gyógyszer-, orvostechnikai eszköz és fertőtlenítőszer felhasználás mennyiségéről és értékéről. Jelenleg az ÁEEK saját portálja, katalógusa fejlesztés alatt áll, tehát a szervezet megtette az első lépést ahhoz, hogy valóban képes legyen az intézményeik igényeit kiszolgálni. Szakértői tapasztalatok alapján a folyamat rendkívül lassan halad, mely akadályozza a központi beszerző szervezet ellátási tevékenységét az intézmények felé.

Különbség van ugyanakkor a KEF és az ÁEEK szabályozása között abban a tekintetben, hogy az ÁEEK megteheti, hogy a keretmegállapodásos eljárás második részében is a központi beszerző szervezet járjon el, nem pedig az ajánlatkérők. Ezt a megoldást jellemzően akkor tudja gördülékenyen alkalmazni a központi beszerző szervezet, amennyiben nagyon pontosan tisztában van az egyes intézmények igényeivel, melyek nem változnak az újraversenyezetés vagy a konzultáció időszaka alatt és megfelelőek, pontosak ahhoz, hogy beszerzésükre az ÁEEK kötelezettséget vállaljon.

A fentiek alapján lehetőség van arra, hogy konzultáció vagy újraversenyeztetés követően újabb keretmegállapodást bonyolítsanak le, melynek eredményeként az ajánlatkérők közvetlenül rendelhetnek a szerződés alapján.

\section{Nemzeti Kommunikációs Hivatal}

A Nemzeti Kommunikációs Hivatalról és a kormányzati kommunikációs beszerzések központosított közbeszerzési rendszeréről szóló 247/2014. (X. 1.) Korm. rendelet értelmében az NKOH bonyolítja le a kommunikációs beszerzéseket. Tevékenységét vizsgálva az NKOH Rendelet alapján az NKOH központi beszerző szervezetnek tekinthető, mely meghatározott kormányzati kommunikációs szolgáltatások és az azokhoz kapcsolódó kommunikációs termékek és szolgáltatások beszerzésével foglalkozik díj ellenében. Az NKOH nem rendelkezik elektronikus katalógussal, beszerzésitárgy-meghatározása igen tág, hiszen a kormányzati kommunikációs feladatokat definiáló melléklet tartalma alapján nagyon sok olyan beszerzési tárgy is rész lesz, melynek közvetlenül a kormányzati 
kommunikációhoz nincs köze. Az utóbbira több szakértő is felhívta a figyelmet. A központosított közbeszerzési tevékenység díj ellenében történik.

Az alanyi hatály meghatározása ennek megfelelően rendkívül tág, gyakorlatilag a tárgyi hatály vonatkozásában releváns beszerzéseket érinti az ún. klasszikus ajánlatkérők vonatkozásában.

Más szerződések átvételével kapcsolatban a felelősségi viszonyok rendezetlenek, gondoljuk különösen uniós forrásból támogatott eljárások esetére. Két interjúalanyunk szerint a modell értelmében az $\mathrm{NKOH}$ átvehet eljárásokat az ajánlatkérőktől előzetes engedélyeztetés keretein belül, mely teljes mértékben egyedi megoldás, ilyen irányba az európai központi beszerző szervezetek ezidáig nem mozdultak el.

A Hivatal feladatkörébe a hagyományos értelemben vett központi beszerző szervezeti feladatkörén túl, ellenőrzési jogkört is kapott. Az engedélyeztetés keretében beszerzési tervet vizsgál, teljesítést ellenőriz, igényt bírál el. Valójában tehát központi beszerző szervezeti tevékenysége mellett olyan felhatalmazással is bír, mely a kommunikációs célú (vagy annak tartott) beszerzéseket egy kézben összpontosítva felügyeli.

Az eljárásrend annyiban különbözik az ÁEEK szabályozásától, hogy a keretmegállapodásos eljárások második részében a verseny újranyitását csak az $\mathrm{NKOH}$ bonyolíthatja, így a hatály alá tartozó intézményeknek még kevesebb szabadságuk van beszerzéseik lebonyolításában.

Összességében, ahogy több szakértő is utalt rá, az NKOH rendkívül tág hatáskörrel rendelkező, a hagyományos központi beszerző szervezetek tevékenységén túlnyúló saját intézmény.

\section{A hazai központosított közbeszerzési modellek főbb működési jellemzői}

A hazai közbeszerzési modellek jellemzője, hogy erősen kontrollált viszonyok között müködnek, kötelező jellegüek. Különbség abban mutatkozik meg közöttük, hogy milyen mértékben adnak szabadságot intézményeiknek a beszerzés során. A három érintett szervezet mindegyike más-más policy-t követ, melyek összehasonlítása a 2. táblázatban látható.

A fentiek alapján látható, hogy mindegyik központi beszerző szervezet kötelező jelleggel folytatja müködését, ugyanakkor közvetlen hatékonysági követelmények, elégedettségmérés beszerzéseik vonatkozásában a közelmúltban nem történt. Ez utóbbit a beszállítókkal közvetlen kapcsolatban álló szakértők is jelezték. A felmerülő problémák leggyakrabban a szervezetek szolgáltatásának hiányosságai, sikertelen keretmegállapodásos eljárások, hosszadalmas eljárásbonyolítás, a központi ellenőrzés időhúzó hatása, valamint magas árairól szólnak. Utóbbi sajátosság elsősorban a keretmegállapodásos eljárásból magából adódik, hiszen semmi mást, mint egy ígérvényt keletkeztet az eljárás adott beszerzési tárgy beszerzésére, azaz a méretgazdaságosság a keretmegállapodásos eljárás első részében nem érhető tettem.

A nyilvánosság biztosítása részleges, hiszen különösen a KEF és az NKOH esetében nem mindenki számára közvetlenül elérhető információ, hogy az ajánlatkérők az egyes szolgáltatásokat, termékeket milyen áron szerzik be. Az egyes szervezetek közbeszerzés-szakmai tevékenysége egészen más jellegü. A KEF stratégiai szerepkörénél fogva, mint a közigazgatás „ellátó szervezete” komolyabb stratégiaalkotási lehetőséget, szabadságot és egyben nagyobb számonkérhetőséget jelenet.

Az NKOH helyzete nemzetközi összehasonlításban nem értékelhető, hiszen külföldön/Európában ilyen szervezet nem létezik, hiszen tevékenységéből adódóan egy beszerzési tárgykörre létrehozott szervezet ellenőrzési és döntési helyzetben van az adott beszerzési tárgy kapcsán. Így valójában, mint ellenőrző szervezet, mely a teljes beszerzés folyamatát átveheti, betöltheti a központi ellenőrzés szerepét, miközben egy-egy nagy eljárás keretében fedi le a piaci igényeket.

Az ÁEEK szolgáltatási hiányosságai továbbra is a nehéz tervezhetőségből adódnak, ugyanakkor az egészségügyi beszerzések fontossága és értelme nem kérdőjelezhető meg. Ez utóbbi szempontra kifejezetten felhívták interjúalanyaink a figyelmet. Az ingyenesség és a keret-

2. táblázat A hazai központosított közbeszerzési modellek működési jellemzői

\begin{tabular}{|c|c|c|c|}
\hline & KEF & ÁEEK & NKOH \\
\hline Tevékenységének tartalma & $\begin{array}{l}\text { Keretmegállapodásos eljárás I. } \\
\text { részének lebonyolítása, egyéb bo- } \\
\text { nyolítási tevékenység opcionális }\end{array}$ & $\begin{array}{l}\text { Keretmegállapodásos eljárás I. } \\
\text { részének lebonyolítása, II. rész } \\
\text { lebonyolítása a központi beszerző } \\
\text { szervezet döntése szerint }\end{array}$ & $\begin{array}{l}\text { Központosított közbeszerzési eljárás } \\
\text { lefolytatása, egyedi eljárás bonyolítás } \\
\text { a központi beszerző szervezet döntése } \\
\text { szerint, teljesítésellenőrzés, beszerzési } \\
\text { terv vizsgálat, engedélyezés }\end{array}$ \\
\hline $\begin{array}{l}\text { Keretmegállapodás I rész } \\
\text { - felelős }\end{array}$ & $\begin{array}{l}\text { Kötelezően a központi beszerző } \\
\text { szervezet }\end{array}$ & $\begin{array}{l}\text { Kötelezően a központi beszerzö } \\
\text { szervezet }\end{array}$ & $\begin{array}{l}\text { Kötelezően a központi beszerző szer- } \\
\text { vezet }\end{array}$ \\
\hline $\begin{array}{l}\text { Keretmegállapodás II rész } \\
\text { - felelős }\end{array}$ & Ajánlatkérő & $\begin{array}{l}\text { Kötelezően a központi beszerző } \\
\text { szervezet, de átengedheti ajánlat- } \\
\text { kérő is }\end{array}$ & $\begin{array}{l}\text { Kötelezően a központi beszerző szerve- } \\
\text { zet, de átengedheti ajánlatkérő is }\end{array}$ \\
\hline $\begin{array}{l}\text { Ajánlatkérő saját köz- } \\
\text { beszerzési eljárásának } \\
\text { átvétele }\end{array}$ & Nem releváns & Nem releváns & $\begin{array}{l}\text { Központi beszerző szervezet döntése } \\
\text { alapján lehetséges }\end{array}$ \\
\hline Díj mértéke & $\begin{array}{l}\text { Kizárólag ténylegesen felmerült } \\
\text { költségek mértékéig terjedhet, } \\
\text { maximum } 2 \% \text {. }\end{array}$ & Ingyenes & $\begin{array}{l}2 \% \text {-a, de legalább nettó kétszázezer és } \\
\text { legfeljebb nettó kétmillió forint }\end{array}$ \\
\hline Központi ellenőrzés & Igen & Igen & Igen \\
\hline Önkéntes csatlakozás & Lehet & Lehet & Lehet \\
\hline
\end{tabular}


megállapodásos eljárások második része lebonyolításának lehetösége azt feltételezi, hogy a szervezet képes pontosan becsülni a felmerült igényeket, melyhez színvonalas informatikai támogatásra van többek között szükség.

Ugyan a három intézmény tevékenysége hasonló, mégis más-más fejlettségi szinten szolgálják ki a piaci igényeket, mely igények elsősorban adott ajánlatkérői csoportok kötelező igénybevétele során keletkeznek. Látva a hazai modelleket az alábbiakban a szakirodalom segítségével szabjuk a hazai központi beszerző szervezetekre azt az elemzési keretrendszert, mely megkönnyíti a korábbiakban tárgyalt három szervezet tevékenységének elemzését, modernizációs törekvéseik irányának meghatározását.

\section{Elemzési keret a központosított közbeszerzés fejlesztéséhez}

A három példa tanulsága, hogy a strukturális megoldások összehasonlításának főbb elemei a gyakorlatban az alábbi szempontok alapján mutatnak eltérést: tevékenyfelosztás, finanszírozás, igénybevétel (önkéntes vagy kötelező), ellenőrzés. Az alábbiakban a szakirodalom, a hazai központi beszerző szervezetek tevékenységének, szabályozásának áttekintése alapján alakítjuk ki azt a keretrendszert, mely a szervezetek modernizációja során segítségül szolgálhat a döntéshozók számára. Ezzel az összegzéssel szintetizálja a szakirodalom és az interjúk során azonosított vizsgálati szempontokat és azok hatását a 3. táblázat. A szempontrendszer összeállításának célja

\section{3. táblázat A központosított közbeszerzés elemzési keretrendszere}

\begin{tabular}{|c|c|c|c|}
\hline & Vizsgálati szempont & & Vizsgálati szempont hatása \\
\hline 1 & Szervezet: & A központi beszerző szervezet felépítése & A szervezet felépítése lapos, mely kevesebb döntési szintet eredményez. \\
\hline 2 & Humán erőforrás: & A humán erőforrás minősége & $\begin{array}{l}\text { A túlzott fluktuáció nem teszi lehetővé, hogy színvonalas belső folya- } \\
\text { matok alakuljanak ki. Jó minőségű munkaerő hatékonyabb beszerzési } \\
\text { eljárás bonyolítást és színvonalasabb szerződéseket eredményez. }\end{array}$ \\
\hline 3 & Szabályozás: & $\begin{array}{l}\text { A szabályozás mértéke, tartalma, színvo- } \\
\text { nala, módosítás gyakorisága }\end{array}$ & $\begin{array}{l}\text { A szabályozás mértéke mérsékel, tartalmára, módosítására a központi } \\
\text { beszerző szervezet maga is közvetlen hatással van. }\end{array}$ \\
\hline 4 & Kommunikáció: & $\begin{array}{l}\text { A központi beszerző szervezet kommuni- } \\
\text { kációja az igénybevevőkkel, ajánlattevők- } \\
\text { kel, jogalkotóval, hatóságokkal }\end{array}$ & $\begin{array}{l}\text { A kommunikáció aktív, a folyamatos tájékoztatás eredményeként visz- } \\
\text { szajelzések alapján maga a szervezet is gyorsabban jut információhoz. }\end{array}$ \\
\hline 5 & Együttmüködés: & $\begin{array}{l}\text { A központi beszerző szervezet együttmü- } \\
\text { ködései az igénybevevőkkel }\end{array}$ & $\begin{array}{l}\text { Az együttmüködés nyomán a központi beszerző szervezet pontosabb in- } \\
\text { formációhoz jut a korábbi beszerzéseket, valamint lehetséges beszerzési } \\
\text { igényeket tekintve, növelve ezzel beszerzési tevékenységének sikerét, } \\
\text { hatékonyságát. }\end{array}$ \\
\hline 6 & Folyamatok: & $\begin{array}{l}\text { A központi beszerző szervezet belső fo- } \\
\text { lyamatai }\end{array}$ & $\begin{array}{l}\text { A belső folyamatok (döntéshozatali, eljárási) szabályozottak, átláthatók, } \\
\text { írott szabályrendszerben is ellenőrizhetők. }\end{array}$ \\
\hline 7 & Piaci kapcsolatok: & $\begin{array}{l}\text { A központi beszerző szervezet és a poten- } \\
\text { ciális ajánlattevők között kapcsolat }\end{array}$ & $\begin{array}{l}\text { A kapcsolat fennállása lehetővé teszi olyan piaci információk eljutását } \\
\text { a központi beszerző szervezethez, mely közvetlenül befolyásolhatja a } \\
\text { beszerzési eljárásokat. }\end{array}$ \\
\hline 8 & Szabadságfok: & $\begin{array}{l}\text { Központi beszerző szervezet döntési sza- } \\
\text { badsága }\end{array}$ & $\begin{array}{l}\text { A döntési szabadság a beszerzési eljárástípus megválasztásától a beszer- } \\
\text { zésre kerülő termékek azonosításáig, aukció lebonyolításáig. }\end{array}$ \\
\hline 9 & Viszonyrendszer: & $\begin{array}{l}\text { Központi beszerző szervezet és az ajánlat- } \\
\text { kérők közötti viszonyrendszer }\end{array}$ & $\begin{array}{l}\text { Az alá-fölé rendeltségi viszony, mely jellemzően a kötelező igénybevé- } \\
\text { telből adódik nem motiválja megfelelően a központi beszerző szerveze- } \\
\text { tet a fejlődésre. }\end{array}$ \\
\hline 10 & Finanszírozás: & A finanszírozása modell & $\begin{array}{l}\text { A finanszírozás fenntarthatósága hosszú távon, mely biztosítja a megfe- } \\
\text { lelő szolgáltatás nyújtását az igénybe vevők számára. }\end{array}$ \\
\hline 11 & Ellenőrzés: & A központi beszerző szervezet ellenőrzése & $\begin{array}{l}\text { A központi beszerző szervezet ellenőrzése nem akadályozza a beszerzés } \\
\text { folyamatát, az ellenőrzés informatikailag erősen támogatott, nem köti le } \\
\text { a központi beszerző szervezet kapacitásait. }\end{array}$ \\
\hline 12 & Tevékenységi kör: & $\begin{array}{l}\text { A központi beszerző szervezet által végzett } \\
\text { szolgáltatás tartalma }\end{array}$ & $\begin{array}{l}\text { A szolgáltatás tartalma lehatárolt, az igénybe vevők pontosan tudják } \\
\text { mire számíthatnak. A szolgáltatás színvonalát a központi beszerző } \\
\text { szervezet méri. }\end{array}$ \\
\hline 13 & Termékportfólió: & $\begin{array}{l}\text { A központi beszerző szervezet által beszer- } \\
\text { zendő termékek, szolgáltatások köre }\end{array}$ & $\begin{array}{l}\text { A termékek, szolgáltatások köre termékcserével kezelhetö, hosszabb } \\
\text { távú piaci kapcsolatok fennállnak. }\end{array}$ \\
\hline 14 & Kartellveszély: & $\begin{array}{l}\text { A központi beszerző szervezet közbeszer- } \\
\text { zési eljárásai során a kartell kialakulásának } \\
\text { kockázata. }\end{array}$ & $\begin{array}{l}\text { A piacdeformációs hatás elemzése, mely abból adódik, hogy a központi } \\
\text { beszerző szervezet olyan nagy eljárásokat indít, melyben az egyetlen vagy } \\
\text { néhány nyertes a teljes piacot lefedheti, megváltoztatva a piaci viszonyokat } \\
\text { a beszerzés során, amennyiben a legnagyobb vevő maga az ajánlatkérő. }\end{array}$ \\
\hline 15 & Fenntarthatóság: & $\begin{array}{l}\text { Zöld, szociális, innovatív szempontok } \\
\text { alkalmazása a beszerzés során }\end{array}$ & $\begin{array}{l}\text { A fenntartható szempontok alkalmazása megvalósul és hatékonyságot } \\
\text { eredményez. }\end{array}$ \\
\hline 16 & Igényfelmérés: & Az igényfelmérés módja és pontossága & $\begin{array}{l}\text { Az igényfelmérés automatikus, informatikailag támogatott, megfelelő } \\
\text { visszacsatolás müködik a beszerzést követően, múltbeli adatok rendel- } \\
\text { kezésre állnak, mely segíti a későbbi igényfelmérést. }\end{array}$ \\
\hline 17 & $\begin{array}{l}\text { Elektronikus beszer- } \\
\text { zési technikák: }\end{array}$ & $\begin{array}{l}\text { Dinamikus Beszerzési Rendszer, elektroni- } \\
\text { kus katalógusok alkalmazása }\end{array}$ & $\begin{array}{l}\text { Kreatív beszerzési technikák alkalmazása során gyorsabb, hatékonyabb } \\
\text { ellátást képes biztosítani a szervezet. Kevésbé szükséges párhuzamos } \\
\text { informatikai megoldások építése. }\end{array}$ \\
\hline 18 & Felelősség: & $\begin{array}{l}\text { A központi beszerző szervezet felelőssége } \\
\text { az eljárások lebonyolítása során. }\end{array}$ & $\begin{array}{l}\text { A központi beszerző szervezet felelőssége az általa vállalt feladatok el- } \\
\text { végzéséig terjed. A pontos igénymeghatározás eredményeként megkötött } \\
\text { keretmegállapodások, keretszerződések kimerülése esetében az üteme- } \\
\text { zett új eljárás lefolytatása is a központi beszerző szervezet felelőssége. }\end{array}$ \\
\hline
\end{tabular}


nem a legjobb megoldás azonosítása, hanem felhívni a figyelmet a központi beszerző szervezetekkel kapcsolatos érvek és ellenérvek bonyolultságára, s rendszerezni a főbb szempontokat.

Bár célunk az vizsgálati szempontok azonosítása és összefüggések feltárása során azok rendszerezése volt, érdemes felfigyelni arra, hogy a szakirodalom és az interjúk között milyen hangsúlybeli eltérés érzékelhető. A szakirodalom jellegzetesen a szervezet jellegére, a folyamatszempontú, szabályozásra, együttműködésre vonatkozó, ellenőrzésre utaló szempontokra van figyelemmel. Nem csupán finanszírozási okokból, de a központi beszerző szervezetek és szolgáltatásaikat igénybevevők közötti alá-fölérendeltségi viszony, vagy az ajánlatkérők önálló döntési jogosultsága szintén esetenként felmerül. Gyakran feltűnik az igények meghatározása, becslése, annak informatikai támogatása elsősorban a méretgazdaságosság biztosítása vonatkozásában. A szakértői interjúk során a szervezeti kérdések és az ehhez kapcsolódó felelősség, a megfelelő szintü verseny biztosítása, továbbá a finanszírozási problémák vetődtek fel, mint a leglényegesebb szempontok. A verseny biztosítása, az esetleges kartell lehetőségének feltárása és elkerülése, továbbá a központosított rendszerben hatékonyabban biztosítható fenntartható szempontok alkalmazása egyértelmüen részét képezi az elméletnek. A jogszabályi környezet a termékportfólió és az elektronikus beszerzési technikák alkalmazását erősíti, melyeket egyébiránt a szakirodalom is jegyez. Ennek oka, hogy a központi beszerző szervezetek a modern beszerzési módszereket, különös tekintettel az elektronikus beszerzési technikákra, dinamikus beszerzési rendszerekre, aktívabban alkalmazzák. A szakcikkekben elsősorban szervezeten belüli, míg a szakértői interjúk során a külső érintettekkel, helyzetekkel, lehetőségekkel kapcsolatos érdeklődés mutatja, hogy az elemzési keretrendszerben más-más hangsúlyok érzékelhetők, függően attól, milyen információforrásból kívánunk ismeretet, adatot meríteni. A szakértői interjúk olyan szempontokkal gazdagították elemzési keretünket, mint az igényfelmérés, az elektronikus beszerzési technikák alkalmazása, valamint a központi beszerző szervezet felelőssége.

A központosítás önmagában hatékony és kevésbé hatékony eredményre is vezethet. Azonban hatékonyságát és sikerét nem lehet egy-egy adat alapján megítélni, sokkal inkább át kell tekinteni valódi tevékenységét és hatását a piacra, illetve a körülmények hatását saját tevékenységére, adottságokat, melyek változtatására kevés az esély. Ebben a keretrendszerben a legfontosabb szempontok azonosítása történt ahhoz, hogy a szervezetrendszer átalakítása, modernizációja megfelelő szakmai keretek között tudjon megvalósulni. A szinergiahatás, a folyamathatékonyság növelése nyomán elérhető hatékonyságnövekedés, az igényfelmérés fejlesztése eredményeként várható piaci pozíció optimalizálása olyan lehetőségek, melyekkel a központi beszerző szervezeteknek, hasonlóan a multinacionális cégekhez, élniük kell. Ellenkező esetben nem a szolgáltató jelleg, hanem a szolgáltatás kötelező igénybevételének jellege fog dominálni, mely folyamatosan csökkenő motivációval és színvonallal párosul. A megújulás jegyében szükséges figyelni a fenti szempontokra és alakítani a hazai központi beszerző szervezetek jövőjét Magyarországon.

További kutatás tárgya lehet a továbbiakban, hogy ezek a jellemzők mennyire érvényesülnek a gyakorlatban és fontos cél-e ezek nyomán megújítani a központosított közbeszerzést. A keretrendszer önmagában kritikus szempontok szerint íródott, hiszen a szakirodalom mellett a szakértők által hangsúlyosnak ítélt elemek kerültek kiemelésre, melyekben egyben a változtatás igénye is megjelenik.

\section{Felhasznált irodalom}

Baily P. - Farmer D. (1994): Beszerzés, stratégia és menedzsment. Budapest: Müszaki Könyvkiadó

Bals, L. - Laine, J.- Mugurusi, G. (2018): Evolving purchasing and supply organisations: A contingency model for structural alternatives.Journal of Purchasing and Supply Management, 24(1), p. 41-58. https://doi. org/10.1016/j.pursup.2017.10.001

Baldi, S. - Vannoni, D. (2017): The impact of centralization on pharmaceutical procurement prices: the role of institutional quality and corruption. Regional Studies, 51(3), p. 426-438. https://doi.org/10.1080/00343404.20 15.1101517

Blair, R. - Janousek, C. L. (2013): Collaborative mechanisms in interlocal cooperation: a longitudinal examination. State and Local Government Review, 45(4), p. 268-282. DOI: 10.1177/0160323X13511647

Dimitri, N. - Dini, F. - Piga, G. (2006): When procurement should be centralized? In: N. Dimitri - G. Piga - G. Spagnolo (eds.): Handbook of procurement. Cambridge: Cambridge University Press

Eriksson, P. E. - Westerberg, M. (2011): Effects of cooperative procurement procedures on construction project performance: A conceptual framework. International Journal of Project Management, 29, p. 197-208. https:// doi.org/10.1016/j.ijproman.2010.01.003

Erridge, A. (2000): Public Procurement. Public Policy and Administration, 15(4), p. 14-24.

Essig, M. (2000): Purchasing consortia as symbiotic relationships: developing the concept of "consortium sourcing". European Journal of Purchasing and Supply Management, 6.1, p. 13-22. https://doi.org/10.1016/ S0969-7012(99)00031-3

Faes, W. - Matthyssens, P. - Vandenbempt, K. (2000): The pursuit of global purchasing synergy. Industrial Marketing Management, 29(6), p. 539-553. https://doi. org/10.1016/S0019-8501(00)00127-9

Grudinschi, D. - Sintonen, S. - Hallikas, J. (2014): Relationship risk perception and determinants of the collaboration fluency of buyer-supplier relationships in public service procurement. Journal of Purchasing and Supply Management, 20 (2), p. 82-91. https://doi. org/10.1016/j.pursup.2014.03.004

Havighurst, C. (1995): Antitrust issues in the joint purchasing of health care. Utah Law Review, 409. http://scholarship.law.duke.edu/cgi/viewcontent.cgi?article=1594 $\&$ context=faculty_scholarship 
Johnston, W. J. - Bonoma, T. V. (1981): The buying center: structure and interaction patterns. The Journal of Marketing, 45(3), p. 143-156.

Johnson, P. F. - Leenders, M. R. - McCue, C. (2003): A comparison of purchasing organizational roles and responsibilities in the public and private sectors. Journal of Public Procurement, 3(1), p. 57-74. https://doi. org/10.1108/JOPP-03-01-2003-B003

Kamann, D. J. - van der Vaart, T. - de Vries, J. (2004): Joint purchasing: theory and practice. International IPSERA Conference

Karjalainen, K. (2011): Estimating the cost effects of purchasing centralization - Empirical evidence from framework agreements in the public sector. Journal of Purchasing and Supply Management, 17(2), p. 87-97. https://doi.org/10.1016/j.pursup.2010.09.001

Kim, K. K. - Umanath, N. S. - Kim, J. Y. - Ahrens, F. - Kim, $B$. (2012): Knowledge complementarity and knowledge exchange in supply channel relationships. International Journal of Information Management, 32 (1), p. 35-49. https://doi.org/10.1016/j.ijinfomgt.2011.05.002

Munson, C. L. (2007): The appeal of partially centralised purchasing policies. International Journal of Procurement Management, 1(1-2), p. 117-143. https://doi. org/10.1504/IJPM.2007.015358

Normann, H. T. - Rösch, J. - Schultz, L. M. (2015): Do buyer groups facilitate collusion? Journal of Economic Behavior \& Organization, 109, p. 72-84. https://doi. org/10.1016/j.jebo.2014.11.004

Nyikos Gy. - Soós G. (2018): Financial instruments in EU cohesion policy and public procurement: Challenges for the 2014-2020 programming period. Public Procurement Law Review, 2018:(32), p. 120-137.

O'Brien, J. (1995): Joint utility purchasing: A case study lane electric cooperative. Management Quarterly, 36 (1), p. 21.

PWC-Ecorys Riport (2011): Public procurement in Europe - Cost and effectiveness a study on procurement regulation. Prepared for the European Commission By PWC-Ecorys, March http://ec.europa.eu/internal_ market/publicprocurement/docs/modernising_rules/ cost-effectiveness_en.pdf

Ranjay, G. - Sytch, M. (2007): Dependence asymmetry and joint dependence in interorganizational relationships: effects of embeddedness on a manufacturer's per- formance in procurement relationships. Administrative Science Quarterly, 52.1, p. 32-69.

Rendon, R. G. - Snider, K. F. (2010): Supply management in American public administration: Towards an academic discipline. Journal of Purchasing and Supply Management, 16, p. 99-108.

Robinson, P. J. - Faris, C. W. - Wind, Y. (1967): Industrial buying and creative marketing. Boston: Allyn \& Bacon

Rozemeijer, F. (2000): How to manage corporate purchasing synergy in a decentralised company? Towards design rules for managing and organising purchasing synergy in decentralised companies. European Journal of Purchasing \& Supply Management, 6(1), p. 5-12. https://doi.org/10.1016/S0969-7012(99)00034-9

Schiele, H. (2007): Supply-management maturity, cost savings and purchasing absorptive capacity: Testing the procurement-performance link. Journal of Purchasing and Supply Management, 13(4), p. 274-293. https://doi. org/10.1016/j.pursup.2007.10.002

Schotanus, F. - Telgen, J. (2007): Developing a typology of organisational forms of cooperative purchasing. Journal of Purchasing and Supply Management, 13(1), p. 53-68. https://doi.org/10.1016/j.pursup.2007.03.002

Smart, A. - Dudas, A. (2007): Developing a decisionmaking framework for implementing purchasing synergy: A case study. International Journal of Physical Distribution \& Logistics Management, 37(1), p. 64-89. https://doi.org/10.1108/09600030710723327

Tella, E. - Virolainen, V. M. (2005): Motives behind purchasing consortia. International Journal of Production Economics, 93, p. 161-168. https://doi.org/10.1016/j. ijpe.2004.06.014

Úbeda, R. - Alsua, C. - Carrasco, N. (2015): Purchasing models and organizational performance: A study of key strategic tools. Journal of Business Research, 68(2), p. 177-188. https://doi.org/10.1016/j.jbusres.2014.09.026

Wang, X. - Zhong, W. - Mei, S. (2005): An analysis on the benefits of joint procurement in e-commerce environment. Chinese Journal of Management Science, 4(13), p. 56-62.

Wang, X. - Zhong, W. - Mei, S. (2006): Analysis of joint procurement coordination mechanism through quantity discounts. Journal of Southeast University (Natural Science Edition), 1, p. 33. 